\title{
Present Situation and Problems of Technology \\ Education in Japan: With Focusing on Technology \\ Education as General Education
}

\author{
Satoshi Fujikawa (Corresponding author) \\ Graduate School of Education, Hokkaido University of Education \\ Japan \\ E-mail: fujikawa.satoshi@a.hokkyodai.ac.jp
}

Takanori Maesako

Graduate School of Human Sciences, Osaka University

Japan

Received: May 11, 2015 Accepted: September 7, 2015 Published: September 29, 2015

doi:10.5296/ire.v3i2.7622 URL: http://dx.doi.org/10.5296/ire.v3i2.7622

\begin{abstract}
This paper summarized the present situation and problems of technology education in Japan, particularly focused on technology education in general education. It was shown that technology education was carried out for a variety of purposes depending on grade and age. On the other hand, it was shown that technology education as general education is limited to the "Technology" of junior high school "Technology \& Home Economics". The study of "Technology" in junior high school covered the basic elements of engineering. In addition, "Technology" was placed on the roles of character formation as well as academic achievement. This paper also discussed the problems related to technology education in general education in Japan in light of international comparisons and the present situation. It was shown that the amount of time dedicated to technology education in Japan was extremely small by international standards.
\end{abstract}

Keywords: Technology Education in Japan, Junior High School, General education, International Comparisons 


\section{Introduction}

The "Convention on Technical and Vocational Education" adopted at the 25th General Assembly of UNESCO (1985) stated that "we must provide an initiation to the world of technology and labor as general education to all children". In national assembly of Japan (1999), the "Basic Act on the Promotion of Core Manufacturing Technology" has been enacted, requiring "enhanced technology education in elementary schools and junior high schools, etc." Kohno et al. (1999) states that "there is a strong trend for academic achievement to be confined to examinations and we should review technology education to allow children to live a full and vigorous life". Ando (2006) also describes technology education as being "essential to human growth and development". Many other researchers have also called for enhanced technology education (Kohno, 1999a; Asada et al., 2010; Harada, 2013a). This is why technology education, backed by international demands, national policies, and the recommendations of researchers, is recognized as one of the important aspects of education in Japan.

This paper summarizes the purpose and content of technology education in Japanese elementary schools, junior high schools, high schools, and universities respectively. This paper particularly focuses on "Technology" in the subject of "Technology \& Home Economics" in junior high school, the only technology education in general education, and describes its purposes and teaching content in great detail. This paper also discusses the issues related to technology education in Japan in light of international comparisons and the current situation in Japan.

\section{Technology Education in Japan}

Technology education is carried out in Japanese elementary schools, junior high schools, high schools, and universities. In elementary schools, there is a subject called "arts and crafts" consisting of activities such as "making models based on materials" and "creating something you want to express in 3D" (MEXT, 2008a). This subject contains rudimentary elements of technology education to give students an interest in making things and nurture fundamental manufacturing skills. However, the primary purpose of "arts and crafts", according to the elementary school curriculum guidelines, is to "foster sensibility" (MEXT, 2008b), and the subject contains many artistic aspects. Although the subject contains rudimentary elements of technology education, the words "technology education" does not appear in the curriculum guidelines or its handbook. The Japan Society of Technology Education, one of the most influential academic societies on technology education in Japan, does not regard "arts and crafts" as technology education, on their leaflet (JSTE, 2014).

In junior high school there is a subject called Technology \& Home Economics which is comprised of "Technology" field and "Home Economics" field. Technology \& Home Economic was a gender- specific subject prior to 1977, with boys learning about "Technology" and girls learning about "Home economics" (MEXT, 2008c). However, the curriculum guidelines redefined this as a coeducational subject in 1989 and both boys and girls are now required to learn both "Technology" and "Home Economics" (Abiko et al., 2009a). The contents of the "Technology" consist of "A. Technology of materials and their 
processing", "B. Technology of energy conversion", "C. Technology of nurturing living things", "D. Technology of information processing" (MEXT, 2008c). The study of Technology field covers the basic elements of engineering. Although the learning content is primarily practical, greater importance is placed on the roles of academic achievement and character formation than on the role of career education (Harada, 2013a). These "Technology" are, in essence, the only technology education in general education. So, technology education in Japanese ordinary education generally refers to the "Technology" of junior high school Technology and Home Economics (Abiko et al., 2009b).

High schools can be generally divided into "ordinary courses" and "specialized courses" (Ando, 2014). There is a subject called "information" (MEXT, 2008d) in ordinary courses in which students learn about computers and multimedia systems. There are various subjects such as industry, agriculture, and information in specialized courses in which students can receive specialized technology education which further expands upon the content of the "Technology" covered in junior high school (MEXT, 2008e). Specialized courses emphasize the aspect of career education, and the majority of students in these courses wish to gain employment after graduating. However, the number of students wishing to proceed to university has been gradually increasing since the 1990s. According to MEXT (2011 a), it was reported that $29.7 \%$ students of specialized courses went on to university.

Universities provide a high level of specialized education related to technology in the faculties of engineering, agriculture, and informatics, etc. Technology education at universities fulfills the role of career education aimed at employment after graduation as well as the role of basic education to foster researchers.

\section{Technology Education under General Education}

As mentioned in Chapter 2, the "Technology" of junior high school "Technology \& Home Economics" is, in essence, the only technology education in general education. The project method, proposed by Kilpatrick (1918), has been used in the teaching of "Technology" for a long time. This method emphasize practical activities such as having students design and devise their own creations and solve their problems with a focus on tasks such as making things. The philosophy of the project method has been inherited in the current Japanese curriculum guidelines. The goals of "Technology" are displayed in Table 1.

Table 1. Goals of "Technology"

To enable students to acquire fundamental and basic knowledge and skills related to materials and their processing, energy conversion, nurturing living things and information processing through practical and hands-on learning activities such as production (monodukuri), and to deepen understanding the relationship between the technology and both society and the environment, while also fostering the ability and attitude to evaluate and utilize technology properly. 
Making things is not the ultimate goal in the study of "Technology"; the goal is to foster "the ability and attitude to evaluate and utilize technology properly." The content and items of the "Technology" are shown in Table 2. All students must complete all the content in Table 2 during their three years of junior high school. A total of 87.5 hours are devoted to these "Technology" in the three years of junior high school: 35 hours in the first year, 35 hours in the second year, and 17.5 hours in the third year.

Table 2. Cntent of "Technology"

\begin{tabular}{ll}
\hline \multicolumn{1}{c}{ Content } & \multicolumn{1}{c}{ Heading } \\
\hline $\begin{array}{l}\text { A. Technology of materials } \\
\text { and their processing }\end{array}$ & $\begin{array}{l}\text { (1) Technology used in our lives and industries. } \\
\text { (3) Design and production of objects applying technology of materials and } \\
\text { their processing. }\end{array}$ \\
\hline $\begin{array}{l}\text { B. Technology of energy } \\
\text { conversion }\end{array}$ & $\begin{array}{l}\text { (1) Mechanism of energy converting devices and their maintenance checks } \\
\text { conversion }\end{array}$ \\
\hline $\begin{array}{l}\text { C. Technology of nurturing } \\
\text { living things }\end{array}$ & $\begin{array}{l}\text { (1) Habitats of living things and technology for nurturing them } \\
\text { (2) Cultivation of plants or animals by applying technology of nurturing }\end{array}$ \\
\hline $\begin{array}{l}\text { living things } \\
\text { information processing }\end{array}$ & $\begin{array}{l}\text { (1) Information and communication networks and information ethics } \\
\text { (2) Design and production of digital works }\end{array}$ \\
\hline
\end{tabular}

Witten by the authors, based on the Course of Study for Junior High Schools (MEXT, 2008c).

\section{Details of the "Technology"}

Based on the Course of Study in Japan (MEXT, 2011b), the authors show the items that should be treated in the learning content, "A. Technology of materials and their processing", "B. Technology of energy conversion", "C. Technology of nurturing living things", "D. Technology of information processing" in the following sections.

\section{A. Technology of materials and their processing}

With regard to "(1) Technology used in our lives and industries" in the learning content of A, on Table2, teacher should treat the following two items; to deliberate the roles of technology in improving our lives and in succession and development of industries; to deliberate the relationship between technological improvements and the environment.

With regard to "(2) materials and their processing methods" in the learning content of A, teacher should treat the following three items; to understand the characteristics of each material and their use; to understand processing methods appropriate for each material and be able to use tools and equipments safely; to deliberate the proper evaluation and the use of technology of materials and their processing. 
With regard to "(3) design and production of objects applying technology of materials and their processing" in the learning content of A, teacher should treat the following three items; to deliberate the functions and structures appropriate for their purposes and usage requirements; to understand the methods for communicating ideas and be able to make a production drawing; to be able to fabricate parts, assemble them and finish products.

\section{B. Technology of energy conversion}

With regard to "(1) Mechanism of energy converting devices and their maintenance checks" in the learning content of B, on Table2, teacher should treat the following three items; to understand energy conversion methods and the mechanisms for power transmission; to understand the basic mechanisms of equipments, and to be able to perform their maintenance checks and to prevent accidents; to deliberate the proper evaluation and use of technology of energy conversion.

With regard to "(2) Design and production of the devices applying the technology of energy conversion" in the learning content of B, teacher should treat the following two items; to be able to select and design the functions and structures required of the products; to be able to assemble and adjust the products, as well as to wire and inspect electric circuits.

\section{Technology of nurturing living things}

With regard to "(1) Habitats of living things and technology for nurturing them" in the learning content of $\mathrm{C}$, on Table2, teacher should treat the following two items; to understand methods for managing the conditions appropriate for nurturing living things and their habitats; to deliberate the proper evaluation and use of technology of nurturing living things.

With regard to "(2) Cultivation of plants or animals by applying technology of nurturing living things" in the learning content of $\mathrm{C}$, teacher should treat the following one item; to be able to draw up the plans to nurture the living things aimed to do so, and to be able to cultivate plants or animals.

\section{Technology of information processing}

With regard to "(1) Information and communication networks and information ethics" in the learning content of $\mathrm{D}$, on Table2, teacher should treat the following four items; to understand the main section of computers and their basic information processing mechanisms; to understand the basic mechanisms for making use of information in the information and communication networks; to understand responsibilities for copyrights and transmitted information and to deliberate information ethics; to deliberate the proper evaluation and use of technology of information processing.

With regard to "(2) Design and production of digital works" in the learning content of D, teacher should treat the following two items; to understand the characteristics of each type of medium and their use, and to be able to design works; to be able to combine various types of media and express the ideas and convey the messages.

With regard to "(3) Automatic measurements and controls via computer programs" in the 
learning content of $\mathrm{D}$, teacher should treat the following two items; to understand the basic mechanisms for automatic measurements and controls using computers; to deliberate the procedures for processing information and be able to create simple programs.

Based on the Course of Study in Japan, the authors showed the items that should be treated in the learning content, "A. Technology of materials and their processing", "B. Technology of energy conversion", "C. Technology of nurturing living things", "D. Technology of information processing" in the following sections. It was confirmed that the study of "Technology" covered the basic elements of engineering. In addition, the learning content was primarily practical and placed on the roles of character formation as well as academic achievement.

The authors can expect the world to be flooded with new products utilizing new technology in the future as a result of advances in technology. Citizens must be able to face this new technology with an accurate understanding of both the positives and negatives it brings with it. The "Technology" in junior high school education, for which the ultimate goals are fostering the ability and attitude to evaluate and utilize technology properly, play an important role in Japanese technology education to that end.

\section{Problem of the technology education as general education in Japan}

As mentioned in Chapter 2, technology education is carried out for a variety of purposes in Japan depending on grade and age. The utility of technology education is recognized and there are many reports on classroom practice according to grade and age (Itakura, 2009; Harada et al., 2014; Fujikawa et al., 2014; Nagao, 2012). However, technology education, as general education, is limited to the "Technology" in junior high school education (JSTE, 2014). Moreover, these "Technology" are only taught for three years.

Let's compare this period with other countries. International comparison of period of technology education, as general education, is displayed in Figure 1.

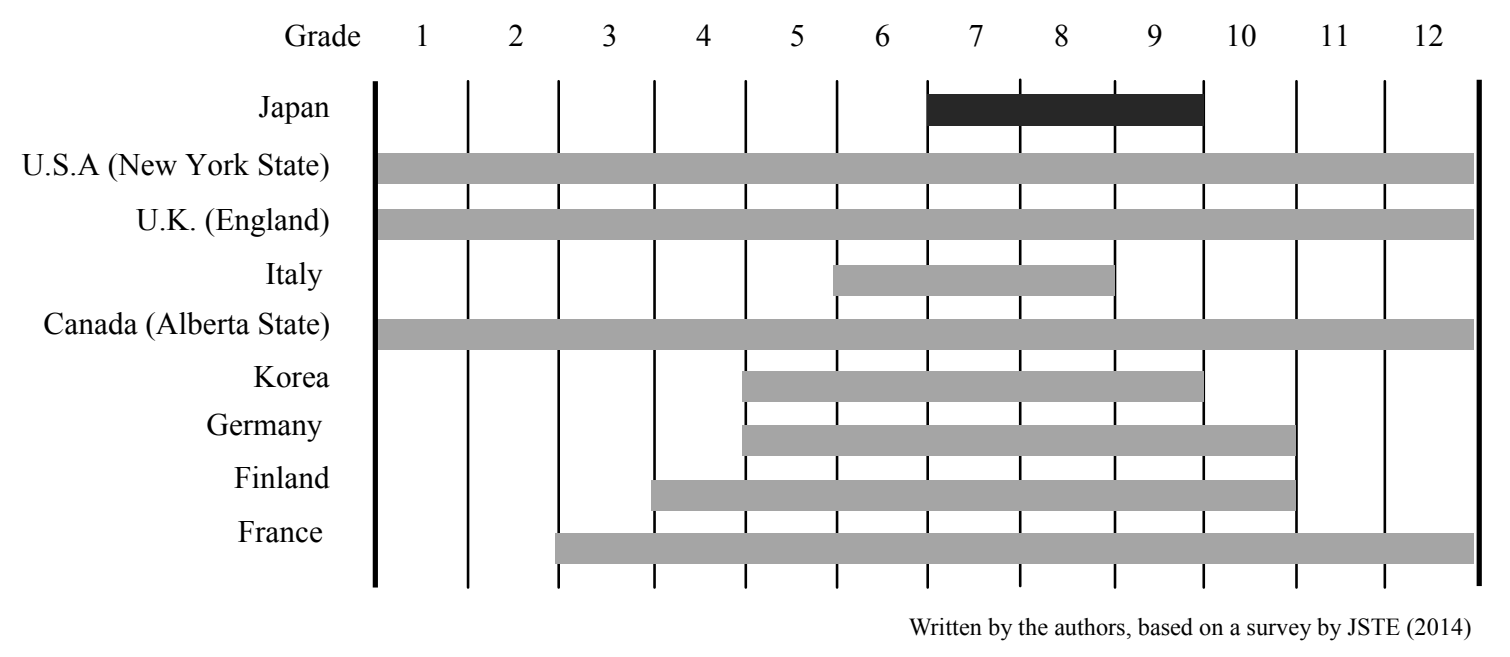

Figure 1. International comparison of period of technology education as general 
In the U.S.A. (New York State) and the U.K. (England), for example, all students complete 12 years of consistent technology education from elementary school to high school. In France, students complete 10 years of consistent technology education. The others, many countries are larger than Japan in regards to period of technology education. Leaving aside the specialized education in universities and limiting our focus to general education, the amount of time dedicated to technology education in Japan can be considered extremely small by international standards. If we want Japanese citizens to reach the minimum internationally accepted level of technical literacy, we should incorporate consistent technology education from elementary school to high school.

Furthermore, the amount of time dedicated to "Technology" is decreasing year by year. The amount of the time dedicate "Technology" is displayed in Table 3.

Table 3. Amount of time dedicated to "Technology"

\begin{tabular}{lllllll}
\hline Revision year & 1958 & 1969 & 1977 & 1989 & 1998 & 2008 \\
\hline Compulsory education $(\mathrm{h})$ & 315 & 315 & 245 & 175 & 87.5 & 87.5 \\
Elective education $(\mathrm{h})$ & 105 & 105 & 35 & 70 & 70 & 0 \\
\hline
\end{tabular}

Written by the authors, based on a survey by Nakazono (2012).

That is why "developing teaching materials for making things that can be easily completed in a short period of time" is becoming an increasingly common theme in recent studies related to teaching materials for "Technology". It is difficult to say the benefits of the project method are sufficiently utilized given this situation. The three years given to "Technology" is not sufficient to achieve the goals shown in Table 1. Harada (2013b) is eager to increase the amount of time dedicated to "Technology" stating that "the unwavering formation of technical knowledge will result from devoting sufficient time to teaching" while evaluating the goals and content of the "Technology". Many researchers share this same idea (Kohno, 1999b; Nakazono, 2012; Fujikawa, 2014). The authors believe that more time should be devoted to these "Technology" given that they are the only technology education in general education in Japan

\section{Conclusion}

This paper summarized the purpose and content of technology education in Japanese elementary schools, junior high schools, high schools, and universities respectively. It was showed that technology education was carried out for a variety of purposes in Japan depending on grade and age. Particularly, this paper focused on "Technology" on the subject of Technology and Home Economics in junior high school, the only technology education in general education, and described its purposes and teaching content in great detail. It was confirmed that the study of "Technology" covered the basic elements of engineering. Moreover, it was confirmed the learning content was primarily practical and placed on the roles of character formation as well as academic achievement. 
This paper also discussed the issues related to technology education as general education in Japan in light of international comparisons and the current situation. It was showed that the amount of time dedicated to technology education in Japan was extremely small by international standards. The authors consider that technology education play an important role for enhancing student various possibilities, so more time should be devoted to technology education in Japan.

\section{Acknowledgement}

The authors would like to thank Dr. Shigeki Ando of Kyoto University of Education for his matchless technical competence and his unfailing loving assistance. In addition, the authors wish to thank Dr. Toshihisa Nishimori of Osaka University for his great instruction in educational technology. Finally, the authors are grateful to Professor Takemi Mizukami of Hokkaido University of Education for his unfailing loving assistant. This work was supported by JSPS KAKENHI Grant Number 26381168.

\section{Reference}

Abiko, H., Ando, S., Uozumi, A., \& Miyakawa, H. (2009a). General Remarks of Technology education: new edition. Aichi, Japan: JSTE. p. 19.

Abiko, H., Ando, S., Uozumi, A., \& Miyakawa, H. (2009b). General Remarks of Technology education: new edition. Aichi, Japan: JSTE. p. 2.

Asada, S., Sato, Y., Shibata, N., \& Doi, T. (2010). A Practical Study on the Significance of Design Process Learning in Technology Education. Journal of Saitama University, 59(1), $33-42$.

Ando, S. (2006). Teaching Materials for Enhancing the Technical Ability on the Process of Educating. Tokyo, Japan: Kazamashobo. p. 2.

Ando, S. (2014). The Reason why Technology Education is necessary: Taketani Booklet. Kyoto, Japan: Taketani Shobo. p. 40.

Fuikawa, S., Tadashi, C., Harada, S., \& Ando, S., (2014). Development and Practice of the Rotating Duty System in Robot Contest Study. International Journal of Innovations in Engineering and Technology, Special Issue-JTL-AEME, 44-50.

Fujikawa, S. (2014). Door for Education: The Boat powered by oar. In A. Shigeki (Eds.), The Reason why Technology Education is necessary: Taketani Booklet (p. 2). Kyoto, Japan: Taketani Shuppan.

Harada, S. (2013a). Aim of Technology Education. In A. Shigeki, H. Shinichi, \& F. Satoshi (Eds.), Theory of Teaching materials in Technology Education (pp. 13-16). Tokyo, Japan: Taketani Shuppan.

Harada, S. (2013b). Monodukuri is a Human Resources Development. In A. Shigeki, S. Harada, \& S. Fujikawa (Eds.), Theory of Teaching materials in Technology Education (p. 153). Kyoto, Japan: Taketani Shuppan. 
Harada, S., Fujikawa, S., \& Ando, S. (2014). Verification of Motivation to Learn and Self-Efficacy in Junior High School Learning of Production (monodukuri). International Journal of Innovations in Engineering and Technology, Special Issue-JTL-AEME, 65-71.

Itakura, Y., \& Suzuki, K. (2009). Educational Practice to Bring up Elementary School Children Interested in Science and Technology. JSME annual meeting, 5, 311-312.

Kilpatrick, W. H. (1918). The Project Method. Teachers College Record, 19(4), 319-335.

Kohno, Y., Otani Y., \& Tanaka, Y. (1999). To Create the Class of Technology Education: To challenge the scholastic ability. Tokyo, Japan: Gakubunsha.

Kohno, Y. (1999a). Junior High School Students and the Lesson on Technology Education. In K. Yoshiaki, O. Yoshimitsu, \& T. Yoshimi (Eds.), To Create the Class of Technology Education: To challenge the scholastic ability (pp. 1-6). Tokyo, Japan: Gakubunsha.

Kohno, Y. (1999b). Present State of the Class in Technology Education. In K. Yoshiaki, O. Yoshimitsu, \& T. Yoshimi (Eds.), To Create the Class of Technology Education: To challenge the scholastic ability (p. 7). Tokyo, Japan: Gakubunsha.

MEXT. (2008a). Commentary to the Course of Study for Elementary schools. Tokyo, Japan: Nihon Bunkyou Shuppan. p. 5.

MEXT. (2008b). Course of Study for Elementary schools, Tokyo, Japan: Tokyo Shoseki. p.71. JSTE. (2014). How the technology educations in the world are currently being enforced?. Retrieved July 30, 2014, form http://www.jste.jp/main/data/sheet4.pdf

MEXT. (2008c). Course of Study for Junior High Schools. Tokyo, Japan: Higashiyama Shobo. pp. 85-91.

MEXT. (2008d). Course of Study for High Schools. Tokyo, Japan: Higashiyama Shobo. pp. 101-104.

MEXT. (2008e). Course of Study for Junior High Schools. Tokyo, Japan: Higashiyama Shobo. pp. 105-225, pp. 253-263.

MEXT. (2011a). Present Situation about High Schools. Retrieved July 30, 2014, fromhttp://www.mext.go.jp/b_menu/shingi/chukyo/chukyo3/047/siryo/_icsFiles/afieldfile/2 013/06/14/1334827_6.pdf

MEXT. (2011b). Section 8 Technology and Home Economics. Retrieved July 30, 2014, from http://www.mext.go.jp/component/a_menu/education/micro_detail/_icsFiles/afieldfile/2011/ 04/11/1298356_9.pdf

Nagao, N. (2012). A Learning Guidance Proposal on Integrated Mechanical and Electrical Fields using Cells at Technical High Schools. Journal of the Japan Society Technology Education, 54(3), 163-170.

Nakazono, M. (2012). The prospect of future education through the past educational practices of the Technical and Homemaking Course. Research Report of Daiichi Institute of 
Technology, 24, 63-74

National Assembly of Japan (1999, Law number: Act No. 2, Article 16.). Basic Act on the Promotion of Core Manufacturing Technology, Tokyo, Japan: National Assembly of Japan.

UNESCO. (1985, November 10). Convention on Technical and Vocational Education adopted by the General Conference of UNESCO at 25th session (p. 5), Paris: UNESCO.

\section{Copyright Disclaimer}

Copyright reserved by the authors.

This article is an open-access article distributed under the terms and conditions of the Creative Commons Attribution license (http://creativecommons.org/licenses/by/3.0/). 